\title{
雜窐录
}

\section{力率分配法に就 て}

(G. S. Coleman: The Moment Distribution Method. Concrete and Constructional Engineering, April 1932.)

(昭和七作十月十八日受理)

渡邊治人抄譯

前 書

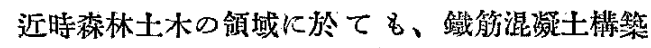
物を建設する必装に迫 られる事が往ネある。此の 場合に生ずる連䍃桁梁の計算は Theorem of three moments 等の高等制學を要するので初學者の目 蓶を感ずるものである。然るに此の困踓は米國 Illinois 大學の Cross 㸚授が案出した力率分配法 (Moment-Distribution Method) 々秛する简易解 法に佬て除かれた榴がある。勿諭之は簡易近似法 であるから絕對 正磪なものではないが、連續折梁 の訣算で最も困難上する虎の、長さの置つた徑间 で、不規則な踔を受け、而も其の斷面が等しくな

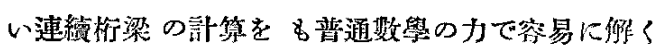
事が出來、日、同楼な方法を繰返すととに依て賽用上 全く差支人のない結果を得られるものである。此 の解法を Coleman 氏が Concrete 誌に紹介して 居るのて、をを抄譯して紾考に供し度いと思ふ。

本文

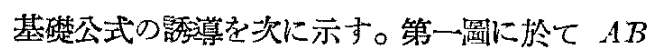
を元承水平な桁とし、夫が $A$ 端及 $B$ 端で外力弯 の作用妾受けて圖示の樣に曲り、B端は $A$ 端上 り下に $\delta$ だけ撓んだとする。

第 一 㖥

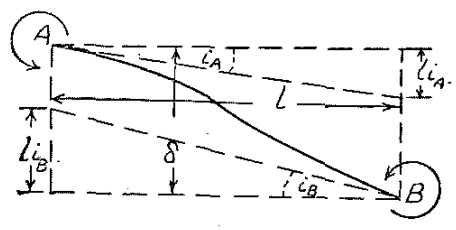

外力率は共に左超りであるから、 $A 、 B$ 間にて 轉曲點を生ずるので之等外力率を區別せねばなら 妨。それで曲心を桁の上方に生ずるものを正力率 とし、下方に生ずるむのを負力率とする。從て $M_{A}$ は真で、 $M_{B}$ は正となる。

今桁の隋率 $I$ は（一定であると假定する）

$$
\int \frac{M d x}{E I}
$$

な与方程式から先づ力率圖の面啧を定めて $i$ 求 める事が出來る。式中 $i$ は傾科角、 $E$ は材料の彈 性力率を示す。力率圆便宜上第二圆に示寸樣に 描き、任意點の力來 $M$ の值は其の點の全縱距で 表は寸樣にする。 $\delta$ の值は小さいるのであつて。

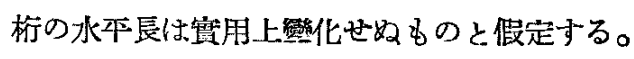

故に、 $i_{B}-i_{A}=\frac{1}{E I}\left(M_{B} \frac{l}{2}-M_{A} \frac{l}{2}\right)$

$$
=\frac{l}{2 E I}\left(M_{B}-M_{A}\right) \cdots \cdots \cdot(i)
$$

撓度は $\int \frac{M x}{E r} d x$ に等しいから、撓度は力率

圖の面積に $B$ 點加ら其の重心に至る距䧺を乘じ て求め得られる。

從て、 $\begin{aligned} \delta-l i_{A} & =\frac{1}{F I}\left(M_{B} \frac{l^{2}}{6}-M_{A} \frac{l^{2}}{3}\right) \\ & =\frac{l^{2}}{6 E I}\left(M_{B}-2 M_{A}\right) \ldots \ldots\end{aligned}$

(I) 式と（2)式を結合して、

$$
M_{A}=\frac{2 E I}{l}\left(2 i_{A}+i_{B}-\frac{3 \delta}{l}\right) \cdots \cdots
$$




$$
M_{B}=\frac{2 E T}{l}\left(2 i_{B}+i_{A}-\frac{3 \delta}{l}\right) \cdots \cdots
$$

若し單位長虽り $w$ なる等布 荷重が桁に加はる と、法の值は埇し $i_{B}$ の值は減ずる。從て $i_{B}-i_{A}$ の値は減少して、附加力等は負に探る。

此の場合は、

$$
\begin{aligned}
& i_{B}-i_{A}=\frac{l}{2 E I}\left(M_{B}-M_{A}-\frac{w l^{2}}{6}\right) \cdots(5) \\
& \delta-i i_{A}=\frac{l^{2}}{6 E I}\left(M_{B}-2 M M_{A}-\frac{v \cdot l^{2}}{4}\right) \cdot(6)
\end{aligned}
$$

(5)式と（6)式老結合して、

$$
M_{A}=\frac{2 E I}{l}\left(2 i_{A}+i_{B}-\frac{3 \delta}{l}\right)-\frac{w l^{2}}{12}(7)
$$

及び $M_{B}=\frac{2 E I}{l}\left(2 i_{B}+i_{A}-\frac{3 \delta}{l}\right)+\frac{\psi l^{2}}{12}(8)$

上式にて注意すべきは、 $M_{A}$ 及 $M_{B}$ の式の未項 は兩端固定の桁に對するものと同一のものであつ て、之等の項は固定力率として知られ、獾立に計 算され得るものである。此の未項の符躆を定むる には次の规則に據る。

外荷重が桁端を左䢙りに趣轉さすならば、正號 を堔り、右䢙りならば負號を探る。

もしも固定桁の外荷重か濟等であるならば、未 項は雨端支持桁の力率圖の面積を定めて之を 除して容易に求める事㤕來る。今の場合には力 率圆の面積は $\frac{w l^{3}}{12}$ であるから末項は $\frac{w l^{2}}{12}$ となる。

$i_{A}$ 及 $i_{B}$ は右建りである加正號とする。便宜 上末項を $m$ で表はす。

若しも $B$ 端が鉸であるならば、 $M_{B}=0$ である 而して、

$$
\begin{aligned}
& M_{A}=\frac{2 E I}{l}\left(2 i_{A}+i_{B}-\frac{3 \delta}{l}\right)-m_{A} \cdots(\vartheta) \\
& M_{B}=\frac{2 E I}{l}\left(2 i_{B}+i_{A}-\frac{3 \delta}{l}\right)+m_{B}=0 \cdot(10)
\end{aligned}
$$

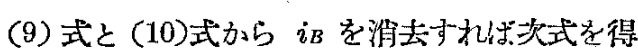

$$
M_{A}=\frac{E I}{l}\left(3 i_{A}-\frac{3 \delta}{l}\right)-\left(m_{A}+\frac{m_{B}}{2}\right) \cdot
$$

往々 $\delta は$ 零に等しい。

以上で基碟公式が誘導されたから、第三圖に示

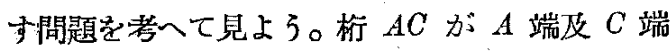
で水平に固定され、 $B$ 點にて支へられて居るもの とする。單苛重 $W$ が $A$ 默加ら $a$ の距䆶に加は
り、 $B C$ 閒には單位長當り $w$ の等布荷重が作用 して居る時、 $A 、 B 、 C$ の各點に拎ける外荷重に因 る才率を決定せんとす。

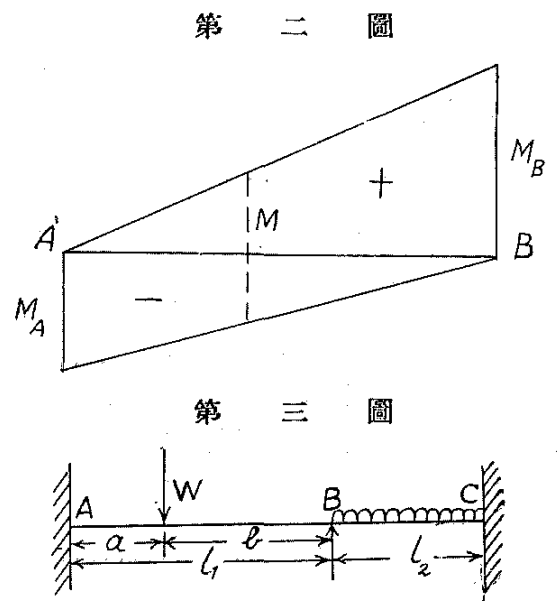

今桁が $B$ 默で水平に緊定されたと假定すれば、 固定力率は $A$ 哭と $B$ 哭の雨側と $C$ 點に生ずる。 $B$ 呫には二個の力率が存在するから $M_{B A}$ 考以て $B$ 㫮の左侧の力率を示し、 $M_{B C}$ を以て右侧の力 率を表はし、mに就いてて同樣とする。

端力率として次のものが得られる。

$$
\begin{aligned}
& m_{A B}=\frac{W a b^{2}}{l_{1}{ }^{2}}, m_{B A}=\frac{W a^{2} b}{l_{1}{ }^{2}}, \\
& m_{B C}=\frac{w l_{n}{ }^{2}}{12}=m_{C B}
\end{aligned}
$$

$W=20$ 顿, $w=1$ 瀬/吹、 $l_{1}=20$ 吹、 $l_{2}=10$ 吹、 $a=5$ 吹及 $b=15$ 吹とす。然る時は $m_{A B}=675$ 时 噸、 $m_{B A}=225$ 吋瀬、 $m_{B C}=100$ 吋噸 $=m_{C B_{\mathrm{O}}}$

$B$ 默が解放されると $B$ 默の雨側の力讋が平衡 する迄析は $B$ 點にて進慱する。 $m_{B A}$ は $m_{B C}$ よ りも大であるから $M_{B C}$ の值は娍じ $M_{B C}$ の値は 增す。支熙は總て同一水平に保つと假定寸れれば、 $i .1$ と $i_{C}$ 及 $\delta$ は零である。

$B$ 點於於ける 万菜の變化は $A$ 點及 $C$ 點の力 率学變化さす故、次に $A$ 點及皮 $C$ 點の力率の變化 を決定せ秋ばならぬ。水平桁 $D E$ (筙四圆)を $D$

第 四圖

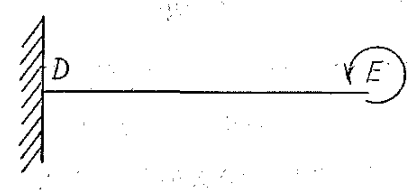


熙にて固定せしめ、 $E$ 哭にてつ力象 $M$ 老作用せし むれば、廷轉て生じる。标には外荷䨘なく、從て $E$ 䁫に㩑度を生じない。從て (4)式から、

$$
M_{E D}=\frac{4 E I}{l} i_{E} \ldots \ldots \ldots \ldots \ldots
$$

(3) 式加占、

$$
M_{D E}=\frac{2 E I}{l} i_{E}
$$

故に枌の一端に力率を加へると他端に其の力寉 の牛分量の力率を生ずる事が制る。從て第三圖の

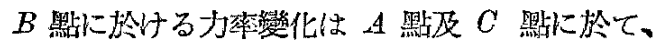
平分量の變化を惹起し、 $A$ 默及 $C$ 點の力率の符 號は $B$ 點に於ける夫れと反對である。

（9）式から端力率が存在せねば、

$$
M_{B C}=\frac{4 E I_{2}}{l_{2}} i_{B}
$$

及(10)式加以、

$$
M_{B A}=\frac{4 E I_{1}}{l_{1}} i_{B}
$$

但、 $I_{1}$ 及 $I_{2}$ は徑間 $l_{1}$ 及 $l_{2}$ に辈する隋率老示 す。

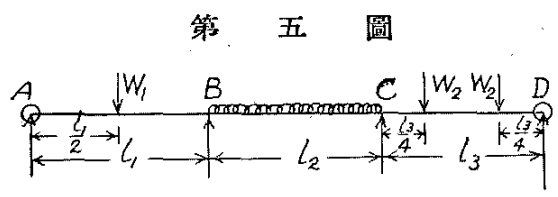

(14) 式及(15)式から、B 點に於ける戀化は $A$ 點及 $C$ 盡力涸定されて居る故に $\frac{I_{1}}{l_{1}}$ 及 $\frac{I_{2}}{l_{2}} に$ 比 例する事が制る。それ故に $B A$ 力率に對する力率 變化は $\frac{I_{1}}{l_{1}}$ に比例し、 $B C$ 力率に對する變化は $\frac{I_{2}}{I_{2}}$ に比例すべし。

今 $I_{1}=I_{2}$ と假定する。然る㭙は變化は $\frac{I}{l_{1}}$ 及 $\frac{I}{l_{2}}$ に比例して、此の場合には $\frac{1}{20}:-\frac{1}{10} \mathrm{~d}^{l_{2}} 1: 2$ の比になる。それ故に、M $M_{D A}$ の變化 $=\frac{1}{3}(225-$ $100)=41.7$ 时顿、文 $M_{E C}$ の變化 $=\frac{2}{3}(225-100)$ $=83.4$ 时瀬。

それ故に、 $M_{B A}=225-41.7=183.3$ 吋顿、及 $M H_{B C}=100+83.4=183.4$ 时顿。

從て $B$ 點の力率は平衡して、此の湯合の $\frac{1}{3}$ 及 $\frac{2}{3}$ を分配因子 (distribution factor) と穛す。 $A$ 繁及 $C$ 默は固定されて居る加ら、か小る因子は存
在しない。

此の平衖法に依て $A$ 䁫及 $B$ 點に傳 洋与る力 率は、(12)式及 (13) 式の結果から、 $M_{A B}$ に對し ては $\frac{1}{2} \times 41.7=20.85$ 时頪、及 $M_{C B}$ に對しては $\frac{1}{2} \times 83.4=41.7$ 时炖頓である。

從て $M C_{C B}=-100+41.7=-58.3$ 吋烧及 $M_{A B}=$ $-675-20.85=-695.85$ 吋瀬。

之等の結果第一表に示す。第三段は $B$ 點が 水平に毉定された際の端力率を表はし、第四段は 平衡量孛與ふ。第五段は $B$ 哭の平衡に因り其の 徑間の反對端に及ぼす影響を示し、符號は反對と なる。第六段は第三段、第四段及第五段の總計で ある。之等の結果は Theorem of Three Moments に化て確證される。

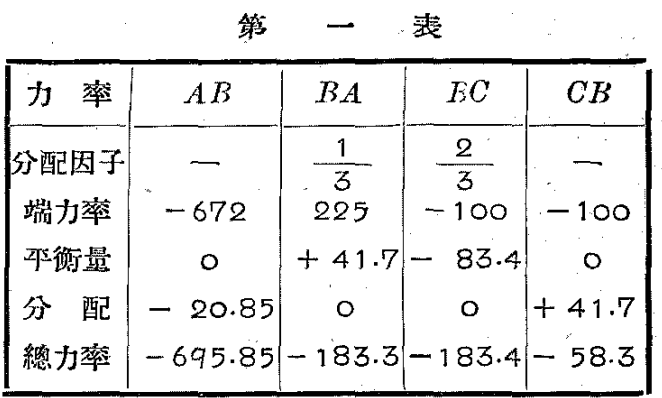

次に析 AECD (第五圖) 考渚一、其の隋率 $I$ 《各徑間に跱して $I_{1} 、 I_{2}$ 及 $I_{3}$ とし、 $A$ 端及 $D$. 端は鉸と寸る。先つ隋率に對する假の值を假定す る事か泌要であるが、而し之は適當の方法で行 はれるであらう。 $A B$ に對する $B$ 點の未項は $\frac{3 W_{1} l_{1}}{16} 、 B C$ に於ける $B$ 點及 $C$ 點に對す

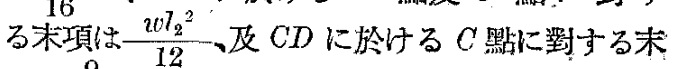
項俚 $\frac{9}{32} \mathrm{~W}_{2} l_{3}$ である。 $M_{A B}$ 及 $M_{D C}$ は零である

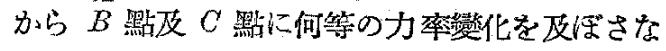
い、從て其の分配因子及平衡量は共に零となる。 今 $B$ 點及 $C$ を敗定し、 $W_{1}=\frac{3}{4}$ 擷、 $i_{1}=12$

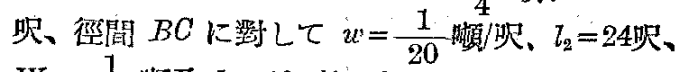
$W_{2}=\frac{1}{2}$ 瀬及 $l_{\mathrm{a}}=16$ 吹とする。然る特は $A B$ に 對与る $B$ 點の末項任 20.25 时噸、 $B C$ に對する $B$ 㫮及 $C$ 點の未項は 28.8 时噸、及 $C D$ に於忛

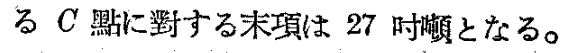

析の一端力周是され、他端力鉸である特に、橈度 の存在せぬ特郎外荷重の舤い場合は、(11)式から 制る椂にMは固定端で $\frac{3 E I}{l} i_{A}$ ナ゙け變化する。 


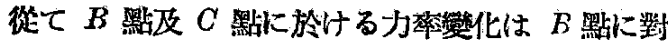
しては $\frac{3 I_{1}}{l_{1}}: \frac{4 I_{a}}{l_{2}}$ に比例し、C嘿に對しては $\frac{4 I_{2}}{l_{2}}$ : $\frac{3 I_{8}}{l_{3}}$ に比例する。

$I_{1}=1200$ 吋 $、 I_{2}=7200$ 时 ${ }^{4}$ 及 $I_{8}=2400$ 吋 $^{4}$ と 寸れい゙、 $\frac{3 I_{1}}{l_{1}}=25 、 \frac{4 I_{3}}{l_{2}}=100$ 及 $\frac{3 I_{3}}{l_{8}}=37.5$ とな る。

從て分配因子は $B A$ に對しては $\frac{25}{25+100}=0.2$ 、 $B C$ に對しては $\frac{100}{25+100}=0.8 、 C B$ に對しては $\frac{100}{100+37.5}=0.73$ 及 $C D$ に對しては $\frac{37.5}{100+37.5}$ $=0.27$ となる。

之等の結果を第二表に示す。

“平衞と分配は其の差が僅少となつて設計者が㴖 足する迄行はるべきである。

總力率の值を每回每に求める必要は璂際には無 い、郎前回の分配に總けて平衡を行ひ、分配が無 意義な程度に㒖少となる迄此の方法を繰返せばよ wo
第 二 践

\begin{tabular}{|c|c|c|c|c|}
\hline 奉 & $B A$ & $B C$ & $C B$ & $C D$ \\
\hline 分配因子 & 0.2 & 0.8 & 0.73 & $0.2^{\prime}$ \\
\hline 端 力 雍 & -20.25 & -28.8 & -28.8 & -27.0 \\
\hline 衡 量 & -1.71 & +6.84 & +1.31 & -0.49 \\
\hline 配 & 0 & -0.65 & -3.42 & o \\
\hline 㮩力萃 & -21.96 & -22.61 & -30.91 & -27.49 \\
\hline 微 量 & -0.13 & +0.52 & +2.49 & -0.93 \\
\hline 配 & 0 & -1.24 & -0.26 & 0 \\
\hline 總力率(2) & -22.09 & -23.33 & -28.68 & -28.42 \\
\hline 平衡量 & -0.25 & +0.99 & +0.19 & -0.07 \\
\hline 分 & 0 & -0.09 & -0.49 & 0 \\
\hline 總力率(3) & -22.34 & -22.43 & -28.98 & -28.49 \\
\hline 平 衡量 & -0.02 & +0.07 & +0.36 & -0.13 \\
\hline 分 & 0 & -0.18 & -0.03 & 0 \\
\hline 總力率(4) & -22.36 & -22.54 & -28.65 & -28.62 \\
\hline 酸 量 & -0.04 & +0.14 & +0.02 & -0.01 \\
\hline & o & -0.01 & -0.07 & 0 \\
\hline 總力 & 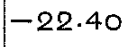 & -22.41 & -28.70 & -28.6 \\
\hline
\end{tabular}

\section{J马य}

\section{一、造 林

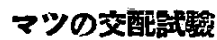

Dengler, A, Künstliche Bestänbungsversuche an Kiefer. Z. f. F. u. J., 1932, Heft 9, S. 513-555. Mit 8 Abbildungen und 10 Tab.

從來森林樹木の受精立に結害に關寸る研究は極 めて尠く、その生理學的方面に就いての我々の知 識は至つて屰弱である。著者はこの默に意を用い Chorin 及び Eberswalde に於てこの力面の嘪驗 を繰返すこと既に多年に亘つてるるのであるが、 热にその成績の一䤃を公にするに至つたものであ る。

實驗の方法は、雄花及び雌花の成熟するを待つ て、注意して一方の花粉を他の渋花に授粉せしめ、
紙袋を以て嚴重に掩ひ、他の花粉を之に附着せし めないやうにするのでせる。開花の時期は、Pinus silvestris に於ては、何れの品種も略同時であつ て、大抵その相互の間で天然の授粉が出來る位て あるが、この宦驗に用ひた外國座 の二種のマッ (banksiana 及び mortana) では、花の時期が非 常に違つてみるので（最初 bunksiana，次が silrestris で、最後が montana)、交配の可能性は甚 だ少い。處女生殖及で處女結實は、2 の例外を除 いては、觀察することが出來なかつた。國內樘の アッの品種の間では相互に容易に交配を行ふこと が出來、相當地地が距つてるる場合でも親䍃關 俰の極近いものであることか解る。 silvestris と banksiana との種間交配に於ては、球果を生ずる ことは膯であるが、多くは粌粒で、發芽力のある 